\title{
First Iowans Settled by Streams
}

\author{
By James Marsh
}

Central Iowa received its first settlers in the 1850 s and early 60s. I came from Illinois to Iowa in 1857. At that time the native prairie-grass was from two to four feet high out on the level. When this grass caught fire it would burn for miles. It was necessary for every farmer to make a good fire guard around his farm, by plowing a strip of land about twenty feet wide.

We settled along the Des Moines river as did most of the early settlers who came into the heart of Iowa. Here we found timber from which to build our log cabins, and the river furnished a means of transportation by flat boat. Fish were abundant in the streams and we obtained large quantities of food from the wild game which roamed the woods in large numbers.

The first settlers of this community built a flat boat of split logs and a few planks which they got from Bruce's Mill. They loaded this boat with their surplus produce of cheese, butter, wheat, and maple sugar; and floated down the river to Des Moines. Here they sold part of their produce and traded the remainder for provisions which they loaded on the boat and poled back up the river.

The first stage coach that came through Iowa ran from Fort Dodge to Boone and Des Moines. One cold January evening the stage, as usual, pulled in at Boone. The horses stopped but the driver did not move. He sat there erect, with the lines in his hands, frozen to death.

The nearest railroad, when we came here in 1857, was at Iowa City. The next railroad into this vicinity was the North Western, which came to Boone in 1866, and two years later the Illinois Central found its way to Ft. Dodge.

The first grist mill in this vicinity was on Boone 
river. This mill was made of two flat stones, with a hollow chiseled in the center. Corn was poured into this, and as the stones were turned in a circular motion the corn was crushed into meal.

We had very few farm implements to work with when we first came here. We would hitch a yoke of oxen onto the bob-sled runner and drive them straight through the field one way and then across the other. This made the two tracks cross at right angles. Then we would go along, drop three kernels of corn in the angle where the two tracks crossed, and step on it to cover it up. When the time came to cultivate it we used a one row walking plow, while the younger boys worked with hoes.

We sowed our wheat broadcast over the field by hand. Then we would go into the timber and cut wild crab apple brush which we would drag by oxen across the field. The long thorns on the brush made it a fairly good drag.

We harvested the wheat by hand with a sickle. We would pile it on a flat place, tramp it out with oxen, and beat it with a flail. When it came time to pick corn we drove the wagon out into the field. Then we would each take a basket, pick it full of corn and empty it into the wagon.

Doctors were almost unknown to us in those days. Our only medicine was taken from the herbs of the woods such as yellow sarsaparilla, bloodroot, prickly ash, elder, snake root, and others.

Dayton, Iowa, June 1925. 
Copyright of Annals of Iowa is the property of State of Iowa, by \& through the State Historical Society of Iowa and its content may not be copied or emailed to multiple sites or posted to a listserv without the copyright holder's express written permission. However, users may print, download, or email articles for individual use. 